\title{
Liver function tests in toxoplasmosis
}

\author{
Nadwa A. J. Mahmood*, Muthear N. Dawood** \\ *Department of Biochemistry, College of Medicine; ${ }^{* *}$ Department of Biochemistry, College of Pharmacy, \\ University of Mosul.
}

(Ann. Coll. Med. Mosul 2012; 38 (2): 68-72).

Received: 24 $4^{\text {th }}$ Oct. 2011; Accepted: $9^{\text {th }}$ Jul. 2012.

\begin{abstract}
Objective: To highlight the possible effects of toxoplasmosis on serum activities of liver enzymes.

Methods: Sixty serologically toxoplasmosis positive women referred to the Public Health Laboratory Centre in Nineveh Province were enrolled during the period from Oct. 2008 - March 2009. Their ages ranged between 16-35 years and mean \pm SD $(24.9 \pm 4.8$ years). Cases were compared with 40 age matched apparently healthy high school, medical college students and employees of Mosul College of Medicine control women who were serologically negative for toxoplasmosis; their ages ranged between 17-35 years and mean \pm SD $(23.9 \pm 5.5$ years $)$.

Serum activities of aspartate aminotransferase (AST), alanine aminotransferase (ALT), alkaline phosphatase (ALP), gamma glutamyl transferase (GGT) and lactate dehydrogenase (LDH) were measured in all cases and controls.

Results: Liver enzymes activities were higher in patients compared with those of the controls.

Conclusion: A probable involvement of the liver in the disease process was noticed for the toxoplasmosis patients although not sufficient to produce clinical signs and symptoms of liver disease.
\end{abstract}

Keywords: Liver enzymes, toxoplasmosis.

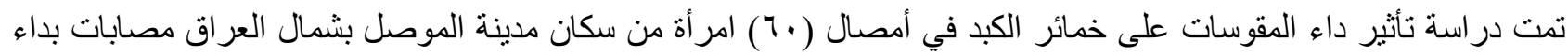

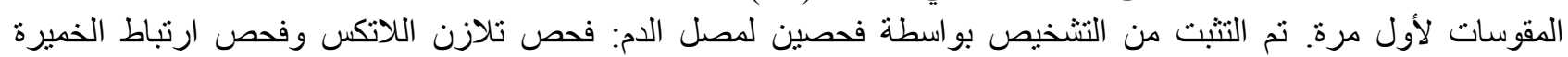

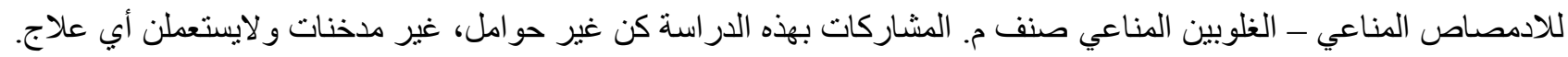

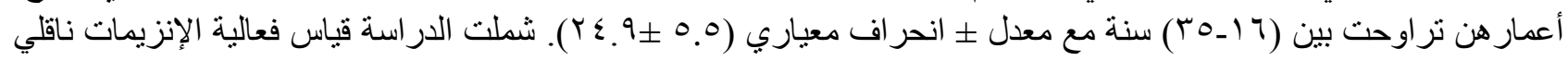

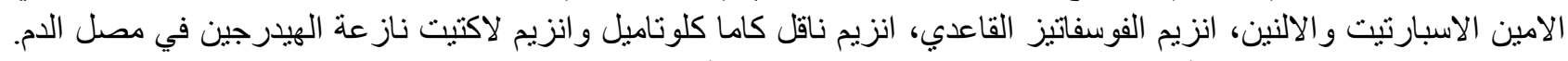

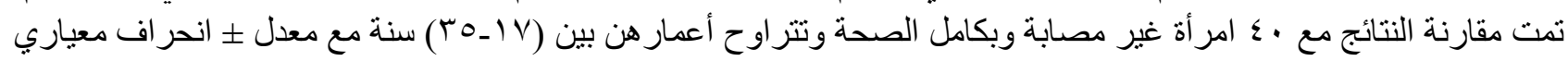

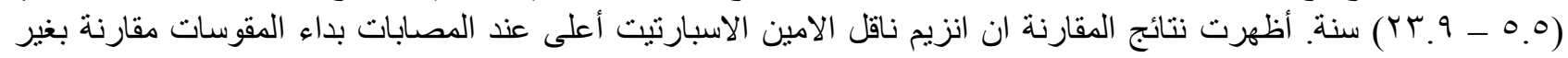

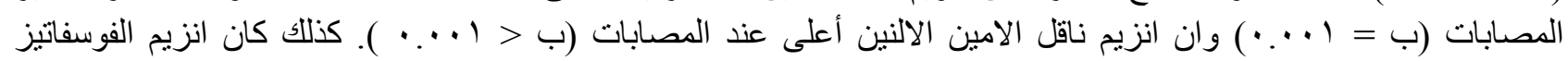

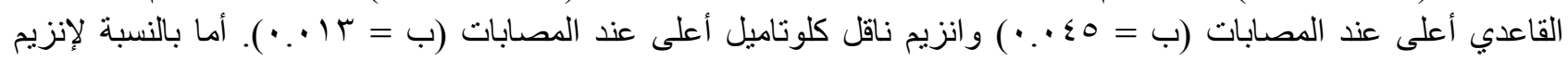

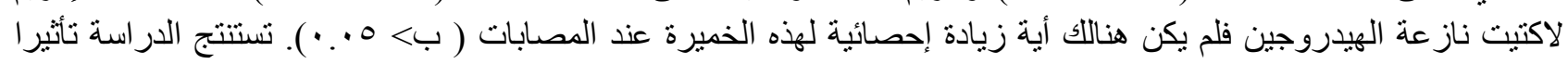

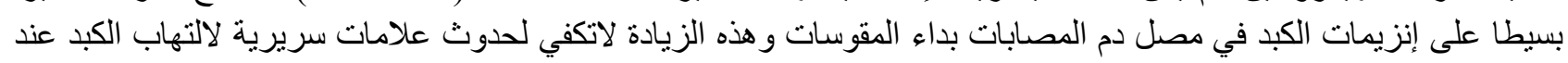

$\mathrm{T}$ oxoplasmosis is a well known protozoal infection that is caused by the parasite Toxoplasma gondii ${ }^{(1)}$ which infests nearly one - third of the world human population ${ }^{(2)}$. Toxoplasmosis could be either congenital where it is transmitted through the placenta ${ }^{(3)}$ or acquired 
by several pathways including contact with contaminated food ${ }^{(4)}$, dust, soil, cats and litter box material. ${ }^{(5)}$ It can be also acquired via transplantation of infected organs, through blood transfusion and through laboratory accidents ${ }^{(6)}$.

Many human and animal studies concerned with the involvement of the liver in cases of toxoplasmosis were published as early as $1965^{(7)}$. Later, an association between toxoplasmosis with hepatomegally and some abnormal liver function tests was found ${ }^{(8)}$. Other studies related the development of granulomatous hepatitis to toxoplasmosis $^{(9)}$. The involvement of the liver in toxoplasmosis with no evidence of symptomatic hepatitis was also attributed to toxoplasmosis ${ }^{(10)}$.

Furthermore, it was reported that cholestatic jaundice may be due to Toxoplasma gondii infection ${ }^{(11)}$, however, other reports suggested that toxoplasmosis could be associated with abnormal liver function tests, round cell infiltration in the portal areas, cholestasis, swollen endothelial cells and/or focal necrosis of liver cells ${ }^{(12)}$. Reports of liver dysfunction in recipients in cases of liver and kidney transplantation were attributed to donors with previous history of toxoplasmosis ${ }^{(13,14)}$.

Experimental animal studies in parallel with human studies further explained some of the pathological liver changes in toxoplasmosis to be due to increased production of interleukin 12 (IL12) and tumor necrosis factor-alpha (TNF- $\alpha$ ) by the Kupffer cells of the liver ${ }^{(15)}$. Other researchers have confirmed this finding and added more explanations like the increase in serum T1cytokines including interferon-gamma (INF- $\mathrm{Y}$ ), TNF- $\alpha, \quad I L-12$ and IL-18. The extent of tissue inflammation is often disproportionate with the presence of parasite suggesting that the pathology is partially immune mediated ${ }^{(16)}$. The Kupffer cells of the liver are part of the immune system in human body and can produce different inflammatory cytokines (TNF- $\alpha$, IL-12, INF- $y$ and $\mathrm{NO}$ ) which may play a role in pathogenesis of liver injury ${ }^{(17)}$.

The aim of the current work is to assess the impact of toxoplasmosis on serum liver enzymes AST, ALT, ALP, GGT and LDH in our locality by comparison with the healthy controls.

\section{SUBJECTS AND METHODS}

The study assessed 60 non- pregnant serologically positive cases with toxoplasmosis diagnosed for the first time referred to the Public Health Center in Nineveh Province. The study was conducted over a period of six months from $1^{\text {st }}$ October 2008 through $31^{\text {st }}$ March 2009; patients' ages ranged between $16-35$ years $(24.9 \pm 4.8$ years). Serological confirmation was by latex agglutination test (LAT) (more than $10 \mathrm{lU} / \mu \mathrm{l}$ ). This test is considered to be a serological screening test for Toxoplasma antibody especially by small laboratories in remote areas due to its availability, simplicity, and sensitivity. It showed $100 \%$ sensitivity but its positive predictive value was only $\left.71.3 \%{ }^{(18)}\right)$.It was followed by Enzyme Linked Immunosorbant Agglutination test (ELISA -lgM). Values of Toxo M index greater than 1.00 were considered positive. A recent study evaluated the sensitivity and specificity of ELISA - IgM; it showed 92\% sensitivity and $100 \%$ specificity which corresponds to $97.4 \%$ negative predictive value and $100 \%$ positive predictive value ${ }^{(19)}$. Patients with positive history of jaundice and liver diseases, drug intake, smoking or any clinical abnormality were excluded from the study. Forty apparently healthy control women were enrolled as a control group. They

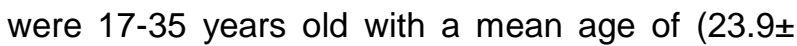
5.5 years). They were all negative for both latex and ELISA -lgM tests.LAT and ELISA were performed at the Public Health Lab. Centre in Mosul. Analysis of enzymes was conducted in the Biochemistry Laboratory - Mosul College of Medicine.

Non-hemolysed serum samples were obtained from patients and controls and divided into two aliquots, the first was used for the serological tests and the second was stored in $-20 C^{\circ}$ for serum enzymes analyses in daily batches. Internal quality controls (IQC) were used within run and batch respectively.

Activities of serum enzymes were measured using kits for AST and ALT method of Reitman \& Frankel ${ }^{(18)}$ (Randox, UK), ALP-method of Kind \& King (19) (BioMerieux, France), GGT- method of Szasz ${ }^{(20)}$ (Biolabo, France) and LDH - method of Henry ${ }^{(21)}$ (Biolabo, France).

Serological tests for toxoplasmosis as a screening test were applied using (LAT) technique ${ }^{(22,23)}$ (Biokit,Spain). The semi quantitative LAT was considered positive when the serum contained more than $10 \mathrm{IU} / \mathrm{ul}$ of toxoplasma antibodies. ELISA IgM test was done using antigen -antibody 
reaction with horse - radish peroxidase forming a conjugate whose reaction is stopped by adding tetramethyl benzidine. The intensity of the colour is preoperational to the amount of $\operatorname{IgM}{ }^{(24)}$. ELISA test was considered positive for $\operatorname{lgM}$ antibody to Toxoplasma gondii if the Toxo M index was 1.00 or greater indicating the probability of current or recent toxoplasmosis. For analysis of data, unpaired student $Z$-test for the comparisons ${ }^{(25)}$.

\section{RESULTS}

Table 1 and Figure 1 show the comparison of serum enzymes activities between the patients and control groups. Serum AST and ALT activities were significantly higher in patients compared to the control at $(p \leq 0.001)$, also did the activities of ALP and GGT $(p<0.05)$. However, the increment in

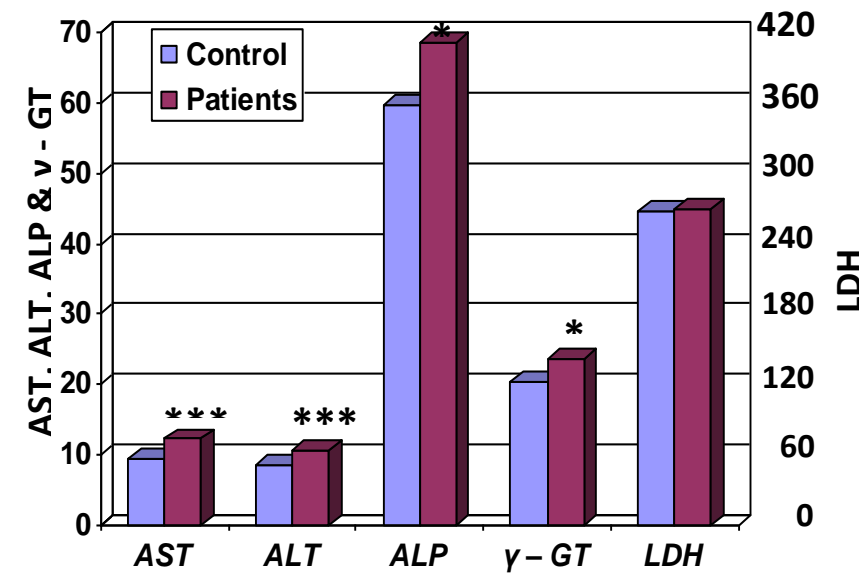

* Significant difference at $p \leq 0.05,{ }^{* * *}$ at $p \leq 0.001$.

Figure 1. Comparison of measured enzymes activities between patients and controls. serum LDH activity was not significant.

Table 1. Comparison of measured serum enzyme activities between patients and controls.

\begin{tabular}{|l|c|c|c|c|c|c|c|}
\hline \multirow{2}{*}{ Liver Enzymes } & \multicolumn{3}{c|}{ Control $(\mathbf{n = 4 0})$} & \multicolumn{2}{c|}{ Patients $(\mathbf{n = 6 0 )}$} & \multirow{2}{*}{ p-value } \\
\cline { 2 - 8 } & Mean \pm SD & Median & Range & Mean \pm SD & Median & Range & \\
\hline AST (IU/L) & $9.57 \pm 3.46$ & 9.0 & $3-18$ & $12.27 \pm 3.62$ & 11.5 & $6.0-21.0$ & $<0.001$ \\
\hline ALT (IU/L) & $8.45 \pm 2.66$ & 8.5 & $4-18$ & $10.58 \pm 3.16$ & 10.0 & $5.0-20.0$ & $<0.001$ \\
\hline ALP (IU/L) & $59.57 \pm 16.97$ & 57.87 & $37.63-114.31$ & $68.57 \pm 23.22$ & 66.39 & $22.01-121.4$ & 0.045 \\
\hline Y - GT (IU/L) & $20.52 \pm 4.72$ & 20.65 & $10.4-29.5$ & $23.36 \pm 5.23$ & 22.7 & $10.7-34.4$ & 0.013 \\
\hline LDH (IU/L) & $267.51 \pm 47.0$ & 262.3 & $197.3-372.4$ & $269.29 \pm 43.2$ & 274.4 & $184.9-356.3$ & (NS) \\
\hline
\end{tabular}

NS $=$ Non- significant at $p<0.05$. Comparisons are by unpaired student's $z$ - test.

\section{DISCUSSION}

Serum AST and ALT activities are excellent markers of hepatocellular injury ${ }^{(26)}$ and serum ALT activity is more specific than serum AST for assessing liver injury ${ }^{(27)}$. The significantly elevated serum activities of aminotransferases in the serologically positive cases of toxoplasmosis in this study are in agreement with several studies ${ }^{(28-}$

${ }^{31)}$. These results also agree with the studies performed on experimental animals ${ }^{(32,35-37)}$.

These elevations suggest the involvement of liver cells. Hepatic necrosis is a well established complication of toxoplasmosis ${ }^{(32)}$ where this infection can cause round cell infiltration in the portal areas, cholestasis, swollen endothelial cells and focal necrosis of liver cells ${ }^{(12)}$. However, despite the significant increase of AST and ALT activities compared with the controls, the levels are still within normal ranges suggesting a mild effect on the liver.
Serum ALP activity was significantly higher in the patients group than that the control $(p=0.045)$. This finding is in agreement with that reported by several studies ${ }^{(31,32,38,39)}$ and could be explained by the presence of Toxoplasma gondii parasites in the bile duct cells since hepatic ALP is reported to be present on the canalicular and luminal domain on bile duct epithelium ${ }^{(28)}$.

Serum GGT activity was significantly higher in the patients group than that of the control $(p=0.013)$ and this is in accordance with previous studies ${ }^{(31,32)}$. This enzyme is liberated from intra and extra duct cells and present in hepatocytes ${ }^{(40)}$. The elevation of this enzyme is more evident than that of serum ALP activity; this may suggest that the bile ducts are involved as well as the hepatocytes in cases of toxoplasmosis. Since GGT is more sensitive than ALP in the diagnosis of obstructive liver disease ${ }^{(41)}$, this will imply that there is definite liver involvement in cases of infected patients. LDH activity showed no 
significant change in both groups, this could be explained on the basis that only a fraction of LDH (isoenzyme LD5) is liver specific ${ }^{(42)}$ and this seems to be in agreement with some other reports ${ }^{(36,43,44)}$. It is obvious that the elevation of serum enzymes activities (except LDH) in this study might suggest liver involvement in toxoplasmosis since the parasite has been reported to be present in different organs including the liver ${ }^{(44,45)}$.

In conclusion, the liver enzymes activities are statistically elevated but they are still within normal acceptable ranges suggesting that toxoplasmosis may affect the liver in a way that this effect is not sufficient to produce clinical signs and symptoms.

\section{REFERENCES}

1. Bhopale G. pathogenesis of toxoplasmosis. Comp immune microbial infect Dis 2003;26:213-222.

2. Tenter A, Heckeroth A, Weiss L. Toxoplasma gondii: from animals to humans. Int $\mathrm{J}$ parasitol 2000;30: 1217 - 1258 .

3. Peterson E. Toxoplasmosis. Semin Fetal Neonatal Med 2007; 12(3): $214-223$.

4. Dubey JP. Advances in the life cycle of Toxoplasma gondii. Int J parasitol 1998;28:1019- 1024.

5. Jalan A. Toxoplasma infection. 2007 [cited 2009 Jan. 6]. Available from: URL:http://www. jalananil. tripod.com.

6. Sciammarella J. Toxoplasmosis. 2002 [cited 2009 Feb. 8]. Available from: URL:http://www.e-Medicine. Com/EMERG/topic601.htm.

7. Remington J, Hackman R. Changes in mouse serum proteins during acute and chronic infection with an intracellular parasite (Toxoplasma gondii). J Immunol 1965;95:1023-1033 [abstract].

8. Jacobs L. Toxoplasmosis: epidemiology and medical importance. J wildl Dis1970; 6: $305-312$.

9. Weitberg A, Alper J, Diamond I, Fligiel Z. Acute granulomatous hepatitis in the course of acquired toxoplasmosis. N Engl J Med 1979; 301: 613.

10. Frenkel J, Remington J. Hepatitis in toxoplasmosis. N Engl J Med 1980;302: 178 - 179.

11. Tiwari I, Rolland C, Popple A. Cholestatic jaundice due to Toxoplasma hepatitis. Postgrad Med 1982; 58: $299-300$.

12. Viranuvatti V. Parasitic diseases of the liver. Medical Forum 1987;22:15 - 19.

13. Wendum D, Carbonell N, Svreek M, Chazouilleres O, Flejou J- F. Fatal disseminated toxoplasmosis in a Toxoplasma seropositive liver transplant recipient. J Clin Pathol 2002; 55: 637 - 640 [abstract].

14. Segall L, Moal M, Doucet L, Kergoat N, Bourbigot B. Toxoplasmosis - associated hemophagocytic syndrome in renal transplantation. Transplant Int 2006; 19 (1): 78 -80 [abstract].

15. Araujo M, Bliss S, Suzuki Y, Alcaraz A, Denkers E, Pearce E. Interleukin - 12 promotes pathologic liver changes and death in mice coinfected with Schistosoma mansoni and Toxoplasma gondii. Infect Immun 2001; 69: 1454 - 1462.

16. Mordue D, Monroy F, Regina M, Dinarello C, Cibley C. Acute toxoplasmosis leads to lethal over production of Th1 cytokines. J Immun 2001;167: 4574-4584.

17. Monshouwer M, Hoebe K. Hepatic dysfunction inflammation. Toxicol In vitro 2003; 17: 681-686.

18. Sukthana $Y$, Chintana $T$, Supatanapong $W$, Siripan C, Lekkla A, Cheabchalrad R. Predictive value of latex agglutination test in screening of toxoplasmosis. Southeast Asian J Trop Med Public Health 2001; 32: $314-318$.

19. Gharavi M, Oormazdi H, Roointan E. a comparative study on sensitivity and specificity of conventional and unconventional $\lg G$ and $\lg M$ assays for diagnosis of toxoplasmosis. Iranian J Publ Health 2008; 37 (4): 42-45.

20. Reitman S, Frankel S. A colorimetric method for the determination of serum glutamic oxalacetic and glutamic pyruvic transaminases. Am J Clin Pathol 1957; 28: 56 -59.

21. Kind $P$, King E. Estimation of plasma alkaline phosphatase by determination of hydrolysed phenol with aminoantipyrene. J Clin Pathol 1954; 7: 322 326.

22. Szasz G. A kinetic photometric method for serum $y$ - glutamyltranspeptidase. Clin Chem 1969;15:124136.

23. Henry $R$ J. Determination of serum lactate dehydrogenase. Am J Clin Path 1974;61:108-112.

24. Gray J, Balfour A, Wreighitt T. Evaluation of a commercial latex agglutination test for detecting antibodies to Toxoplama gondii. Serodiag Immunoth Infect Dis 1990;4: 335 - 340.

25. Dunford P, Johnson J. Detection of Toxoplasma specific immunoglobulin - G: assessment of a slide agglutination test. Med Lab Sci 1991; 48:137 - 141.

26. Roller A, Bartlett A, Bidwell D. Enzyme Immunoassay with special reference ELISA technique. J Clin Path 1987; 31: 507 - 520.

27. Armitage P, Berry G. Statistical methods in medical research $2^{\text {nd }}$ ed. Blackwell, Oxford, London, UK. 1985. p. $60-75$

28. Limdi J, Hyde G. Evaluation of abnormal liver function tests. Post Med 2003; 79: $307-312$.

29. Moss D. Liver function tests. Med Int 1994; 22(11): $425-431$.

30. Sacks J, Dennis G, Lobel H, Parker R. Toxoplasmosis infection associated with eating 
undercooked venison. Am J Epidemiol 1983; 118 (6): 832-838 [abstract].

31. Ortego T, Robey B, Morrison D, Chan C. Toxoplasmic chorioretinitis and hepatic granulomatous. Am J gastroenterol 1990; 85(10): 1418 - 1420.

32. Paspalaki P, Mihailidou E, Bitsori M, Tsagkaraki D, Mantzouranis E. Polymyositis and myocarditis associated with acquired toxoplasmosis in an immunocompetent girl. 2001 [Citied 2009 Jan 4]. Available from: URL:http://www.biomedcentral. com.

33. Carme B, Bissuel F, Ajzenberg D, et al. Severe acquired toxoplasmosis in immunocompetent adult patients in French Guiana. J Clin Microbiol 2002; 40(11): 4037 - 4044.

34. Rifatt M, Salem S, Azab M, Beshir S, Safer E, El Shennawy S. Effect of Toxoplasma gondii on histopathology and histochemistry or reticuloendothelial system in experimental animals. Folia Parasitol 1981; 28(2):117- 124 [abstract].

35. Marshal A, Denkers E. Toxoplasma gondii triggers granulocyte - dependant cytokine - mediated lethal shock in D- galactosamine - sensitized mice. Infect Immun 1998; 66 (4): 1325 - 1333.

36. Bresciani K, Toniollo G, Costa A, Sabatini G, Moraes F. Clinical, parasitological and obstetric observations in pregnant bitches with experimental toxoplasmosis. Cienc Rural 2001; 31(6):1039 1043.

37. Yarim G F, Nisbet C, Oncel T, Cenesiz S, Ciftci G. Serum protein alterations in dogs naturally infected with Toxoplasma gondii. Parasitol Res 2007; 101 (5): $1197-1202$.
38. Vilaseca J, Guardia J, Cuxart A, et al. Granulomatous hepatitis: aetiological study of 107 cases. Nouv Presse Med 1978; 7 (37): 3323-3325 [abstract].

39. Bonacini M, Kanal G, Alamy M. Duodenal and hepatic toxoplasmosis in patients with HIV infection: review of the literature. Am J Gastroenterol 1996; 91 (9): $1838-1840$ [abstract].

40. Rosenthal P. Assessing liver function and hyperbilirubinemia in the newborn. Clin Chem 1997; 43 (1): $228-234$.

41. Dufour R, Lott J, Nolte F, Gretch D, Koff R, Seeff L . Diagnosis and Monitoring of Hepatic Injury. I. Performance Characteristics of Laboratory Test. Clin Chem 2000; 46: 2027 - 2049.

42. Smith A, Beckett G, Walker S, Rae P. Lecture notes on clinical biochemistry. $6^{\text {th }}$ ed. Blackwell science, Oxford, London, UK 1998. p. 110 - 141.

43. Moscatelli G, Altcheh J, Biancardi M, Lapea A, Ballering, Freilij $\mathrm{H}$. Acute toxoplasmosis: clinical and laboratory data in eleven patients. An Pediater 2006; 65:551-555

44. Joseph P, Calderon M, Gilman R, et al. Optimization and evaluation of a PCR assay for detecting toxoplasmic infection. J Clin Microbiol 2002;40 (12): 4499 - 4503.

45. Dubey JP. Toxoplasmosis - a waterborne zoonosis. Vet parasitol 2004; 126: $57-72$. 